\title{
Utilization Ceramic Wastes from Porcelain Ceramic Industry in Lightweight Aggregate Concrete
}

\author{
Rungroj Piyaphanuwat and Suwimol Asavapisit
}

\begin{abstract}
This research investigated the possibility of ceramic wastes such as deteriorated working mold (DWM) and biscuit as a coarse and fine aggregate in lightweight aggregate concrete (LWAC), which divided to two parts; effect of coarse aggregate (CA) replacement with DWM and effect of biscuit replacement fine aggregate (FA)on properties of LWAC.The ratio of ordinary Portland cement (OPC): FA: CA are 1: 2.21: 3.03 and replaced CA with DWM and FA with biscuit at the levels of $0,25,50,75$ and $100 \mathrm{wt} \%$. All conditions of LWAC were tested for compressive strength at $7,14,28$ and 56 days, unit weight, water absorption and thermal conductivity at the age of 28 day. The results showed that increasing the levels of DWM decreased density and compressive strength but increased the water adsorption and thermal conductivity. At 28 days, the compressive strength and bulk density of LWAC decreased from 55.4 to $11.4 \mathrm{MPa}$ and 2394 to $1362 \mathrm{~kg} / \mathrm{m3}$ with increasing of DWM replaced CA from 0 to $100 \mathrm{wt} \%$. The optimum ratio of lightweight aggregate concrete with DWM was the level of $50 \mathrm{wt} . \%$ that gave the compressive strength and density at 28 days of $38.1 \mathrm{MPa}$ and $1803 \mathrm{~kg} / \mathrm{m3}$ respectively. This mix was collected to study the effect of biscuit replaced FA on mechanical properties. The compressive strength increased when levels of biscuit increased from 0 to $50 \mathrm{wt} \%$ but decreased with the levels of biscuit excess $50 \mathrm{wt} . \%$. The bulk density and thermal conductivity decreased from 1803 to 1584 $\mathrm{kg} / \mathrm{m} 3$ and 0.689 to $0.592 \mathrm{~W} / \mathrm{m}^{\circ} \mathrm{K}$. The optimum mix of LWAC was found in LWAC containing $50 \mathrm{wt} \%$ of DWM and 100 wt.\% of biscuit that meet the ASTM C330: standard range for structural lightweight aggregate concrete.
\end{abstract}

Index Terms-Lightweight aggregate concrete, working mold, biscuit, compressive strength, thermal conductivity.

\section{INTRODUCTION}

Lightweight concrete defined as a type of concrete which includes an expanding agent in that it increases the volume of the mixture. It is lighter than the conventional concrete that was lower than $800 \mathrm{~kg} / \mathrm{m} 3$. The use of lightweight concrete has been widely spread across countries such as USA, United Kingdom, Sweden, Thailand etc. The lightweight concrete are low density and thermal conductivity. So its advantages are that there is a reduction of dead load, faster building rates in construction and lower transport and handling costs.

Manuscript received October 24, 2016; revised December 20, 2016. This research was funded for presentation from the financial support in publishing academic work from King Mongkut's University of Technology Thonburi.

R. Piyaphanuwat is with the King Mongkut's University of Technology Thonburi (Ratchaburi), Ratchaburi, Thailand (e-mail: rungroj.piy@kmutt.ac.th).

S. Asavapisit is with Environmental Technology, School of Energy, Environmental and Materials, KMUTT, Bangkok, Thailand (e-mail: suwimol.asa@kmutt.ac.th).
Lightweight concrete maintains its large voids and not forming laitance layers or cement films when placed on the wall. Lightweight concretes can either be lightweight aggregate concrete, foamed concrete or autoclaved aerated concrete (AAC). Lightweight concrete blocks are often used in house construction.

Lightweight aggregate concrete can be produced using a variety of lightweight aggregates. Lightweight aggregates originate from either natural materials, thermal treatment of natural raw materials, by-products from industrial. Volcanic pumice, clay, slate, shale, fly ash, oil palm shell ash, biscuit ceramics, bottom fly ash etc. were used be lightweight aggregate in concrete [1]-[6]. The required engineering properties of lightweight concrete will have a bearing on the best type of lightweight aggregate to use. It is a little structural, but high thermal insulation properties, are needed a light, weak aggregate can be used. The LWAC have an air dry density not exceeding $2000 \mathrm{~kg} / \mathrm{m} 3$, but can be as low as $400 \mathrm{~kg} / \mathrm{m} 3$ depending on the materials used and the compressive strength can vary between 1 and $65 \mathrm{MPa}$ [7]. The LWAC was generally being designed in accordance with ACI 213R-04 [8].

The environmental issues are important and interested in industrial sector. The small, medium and large industrials generate pollution such as water, air, solid, hazardous and noise. In ceramic industries, they are the one of industries that generate solid wastes from process such as biscuit, deteriorated working mold etc. The biscuit is defected final product such as porcelain, or unglazed earthenware, often called terracotta, or, most commonly, an intermediary stage in a glazed final product. The working molds are dumped before expiry or deterioration. From the ministry of industry (Thailand) found that the amount of deteriorated working mold is more than 38,000 tons/year [9]. Generally, the management of working mold waste can used in various manufacture industry such as cement industry, the gypsum is added into a clinker about 3-5 wt.\% of cement weight and made the ceiling that it's used in small quantities. In addition, the ceramic production have broken ceramic wastes about $5 \%$ of ceramic products. Both most working mold and biscuit are dumped or land filled which are inappropriate methods. It increasing the risk of hydrogen sulfide gas and causes the global warming. From the property of DWM and biscuit which have a lower density than normal coarse and fine aggregate. It is possibly replacement of CA and FA in LWAC. This research study the optimal ratio of lightweight aggregate concrete with deteriorated working mold (DWM) and biscuit as aggregate The compressive strength, bulk density, water absorption and thermal conductivity of LWAC were investigated. 


\section{MATERIALS}

The DWM and biscuit in this research were obtained from ceramics production process and grounded into small pieces of about 4.75 to $19 \mathrm{~mm}$ for DWM as CA and 0.075 to 4.75 $\mathrm{mm}$. for biscuit as FA. Fig. 1 showed both ceramic waste compared with crushed stone and river sand. The chemical properties of the DWM and biscuit shown in Table I. The working mold consisted mainly of $\mathrm{SO}_{3}$ and $\mathrm{CaO}$ since its chemical compound of calcium sulfate hydrate or gypsum which made the working mold. Major chemical composition of biscuit is $\mathrm{SiO}_{2}$ and $\mathrm{Al}_{2} \mathrm{O}_{3}$. The physical properties of wastes ceramics showed in Table II. Both DWM and biscuit have the specific gravity, bulk density and fine modulus lower than compared with CA and FA. The crushed stone and river sand as coarse and fine aggregate. The physical properties of both aggregate showed in Table II. In addition, ordinary Portland cement (OPC) was used as binder that has specific gravity of 3.15 .

\begin{tabular}{ccc}
\multicolumn{2}{c}{ TABLE I: CHEMICAL COMPOSITION CERAMIC WASTES } \\
\hline \hline $\begin{array}{c}\text { Chemical } \\
\text { Content }\end{array}$ & $\begin{array}{c}\text { DWM } \\
\text { (\% by dry mass })\end{array}$ & $\begin{array}{c}\text { Biscuit } \\
\text { (\% by dry mass })\end{array}$ \\
\hline $\mathrm{SO}_{3}$ & 54.5 & - \\
$\mathrm{CaO}$ & 45.0 & 0.23 \\
$\mathrm{SiO}_{2}$ & 0.162 & 67.90 \\
$\mathrm{SrO}$ & 0.112 & - \\
$\mathrm{Fe}_{2} \mathrm{O}_{3}$ & 0.055 & 0.49 \\
$\mathrm{Al}_{2} \mathrm{O}_{3}$ & 0.047 & 27.92 \\
$\mathrm{MgO}$ & 0.044 & 0.16 \\
$\mathrm{Na}_{2} \mathrm{O}$ & 0.033 & 0.40 \\
$\mathrm{Cl}$ & 0.031 & - \\
$\mathrm{K}_{2} \mathrm{O}$ & 0.010 & 2.81 \\
$\mathrm{CuO}$ & 0.008 & - \\
\hline \hline
\end{tabular}

\section{MIX PROPORTION}

\section{A. Mix Proportions}

This paper investigated the effects of replacement of working mold and biscuit as coarse and fine aggregate on the engineering properties of LWAC. Mix proportion of LWAC was 1: 2.21: 3 which is designed in according the American Concrete Institute (ACI211.1). The first part study the effect of levels of DWM in order to replace the coarse aggregate at the levels of $0,25,50,75$ and 100 wt.\%of gravel and investigated the compressive strength, bulk density and water adsorption. The second part study collect the optimum ratio of LWAC and studied the substitution of biscuit at levels of 0 , $25,50,75$ and 100 wt.\% of sand on the engineering properties. All mix proportions are showed in Table III. The water content of all mixed used slump test that was performed to evaluated the workability of the fresh concrete in accordance with ASTM C143M-05 [10]. The controlled slump for all samples was 8 to $10 \mathrm{~cm}$. The all specimens were cast in standard steel molds with the size of $150 \times 150 \times 150$ $\mathrm{mm}$ of cubes. After first day, all samples were removed from molds and cured in the water.

\section{Method OF TeSTING}

The engineering properties such as compressive strength, bulk density, water absorption and thermal conductivity were investigated. Compressive strengths of LWAC at 7, 14, 28 and 56 days were tested in according with ASTM C39-15 [11] and ACI 213R-04 [12]. A set of five samples was used for compression testing at each curing duration and the arithmetic average was taken. Bulk densities and water absorptions of LWAC at 28 days were tested in according with ASTM C642-13 [13]. In addition, the optimum of LWAC were collected to investigate the thermal conductivity using hot-wire method following ASTM C1113-04 [14].

TABLE II: PHYSICAL PROPERTIES OF THE AGGREGATES

\begin{tabular}{|c|c|c|c|c|}
\hline \multirow[b]{2}{*}{ Physical Properties } & \multicolumn{2}{|c|}{ Coarse Aggregates } & \multicolumn{2}{|c|}{ Fine Aggregates } \\
\hline & DWM & $\begin{array}{l}\text { Crushed } \\
\text { stone }\end{array}$ & Biscuit & $\begin{array}{l}\text { River } \\
\text { Sand }\end{array}$ \\
\hline Specific gravity & 1.78 & 2.58 & 2.16 & 2.40 \\
\hline Apparent density $\left(\mathrm{kg} / \mathrm{m}^{3}\right)$ & 1772 & 2572 & 2236 & 2542 \\
\hline Bulk density $\left(\mathrm{kg} / \mathrm{m}^{3}\right)$ & 1016 & 2542 & 2156 & 2402 \\
\hline Water absorption, $24 \mathrm{hr}$. & & & & \\
\hline$(\%)$ & 41.27 & 0.50 & 5.79 & 3.68 \\
\hline Fine modulus & 2.44 & 2.17 & 2.77 & 2.83 \\
\hline \multicolumn{5}{|c|}{ Grading } \\
\hline Sieve size (mm.) & \multicolumn{4}{|c|}{ Cumulative $\%$ by weight passing } \\
\hline 25 & 98.69 & 98.51 & - & - \\
\hline 19 & 93.5 & 91.3 & - & - \\
\hline 12.5 & 38.5 & 56.5 & - & - \\
\hline 9.5 & 25.25 & 36.43 & - & - \\
\hline 4.75 & 0 & 0 & 97.82 & 98.74 \\
\hline 2.36 & - & - & 90.32 & 92.42 \\
\hline 1.18 & - & - & 78.43 & 87.54 \\
\hline 0.6 & - & - & 50.89 & 58.05 \\
\hline 0.3 & - & - & 11.87 & 49.65 \\
\hline 0.15 & - & - & 2.22 & 21.09 \\
\hline 0.075 & - & - & 0.06 & 10.02 \\
\hline
\end{tabular}

TABLE III: MIX PROPORTIONS OF LWAC

\begin{tabular}{lll} 
MIX & OPC:FA(BISCUIT:):CA (GRAVE:DWM) & W/C \\
\hline Control & $1: 2.21: 3.03(100: 0)$ & 0.62 \\
WM-25 & $1: 2.21: 3.03(75: 25)$ & 0.68 \\
WM-50 & $1: 2.21: 3.03(50: 50)$ & 0.73 \\
WM-75 & $1: 2.21: 3.03(25: 75)$ & 0.75 \\
WM-100 & $1: 2.21: 3.03(0: 100)$ & 0.78 \\
WM-525 & $1: 2.21(25: 75): 3.03(50: 50)$ & 0.73 \\
WM-550 & $1: 2.21(50: 50): 3.03(50: 50)$ & 0.77 \\
WM-575 & $1: 2.21(75: 25): 3.03(50: 50)$ & 0.79 \\
WM-510 & $1: 2.21(0: 100): 3.03(50: 50)$ & 0.80 \\
\hline \hline
\end{tabular}

\section{RESUlTS AND DISCUSSION}

\section{A. Effect of Deteriorated Working Mold as Coarse Aggregate on Engineering Properties of LWAC}

Fig. 1 show the compressive strength of LWAC replacing the gravel with DWM. Increasing level of replacement of DWM resulted in reduction of compressive strength. At 28-day compressive strength of the normal concrete was 55.4 $\mathrm{MPa}$ and decreased to 11.4 MPa, when DWM was added 100 wt.\% of gravel. The compressive strength of all LWAC the concrete demonstrated a decreasing tendency with increasing the percentage of DWM content. Compared to the normal concrete, replacement of DWM in concrete reduced the compressive strength about 23 to $79 \%$ compared with normal concrete. This was cause of adsorption of DWM aggregate (about $41 \mathrm{wt} . \%$ ) that is able to absorb mixing water more than crushed stone (about $0.5 \mathrm{wt} \%$ ) and resulted in water to cement ratio of LWAC [15]. After mixing, some 
water was used to react with ordinary Portland cement to produce hydration product while remained water in pore was evaporated that resulted in pore in matrix. It was cause of reduction of compressive strength of LWAC. At $100 \mathrm{wt} . \%$ of DWM replaced in LWAC get the compressive strength was lower than $17 \mathrm{MPa}$ that did not still in the standard range for structural lightweight aggregate concrete (ASTM C330) [16].

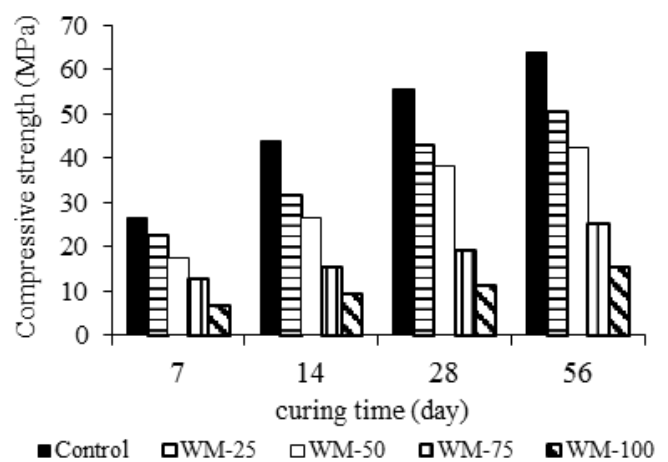

Fig. 1. Compressive strength of LWAC.

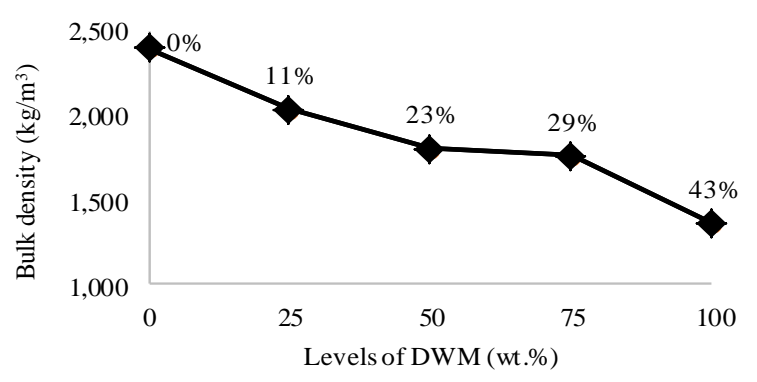

Fig. 2. Bulk density and percentage of reduction of LWAC at 28 days.

In addition, increasing of the level of replacement of DWM in LWAC effected to reduction of density (Fig. 2). This was caused of increasing of water to cement ratio that leaded to high porosity in LWAC matrix. The W/C of normal concrete was 0.62 and increased to 0.78 with 100 wt.\% of DMW were replaced in mix. It was cause of a diluted cement concentration in paste that was cause of cracking and shrinkage after cement paste set. The high shrinkage and high exceed water of concrete leads to micro-cracks, which are zones of weakness [15]. In addition, increase of substitution of DWM resulted in the reduced the bulk density of LWAC because of density of DWM is lower than a crushed stone that about (2.58 to 1.78 ) that show Table II. At 28 days, the bulk density of normal concrete was $2394 \mathrm{~kg} / \mathrm{m}^{3}$ and decreased to 2030, 1803, 1757 and $1362 \mathrm{~kg} / \mathrm{m} 3$ when the level of replacement of DWM increased from 25 to 100 wt.\%. Compared to the normal concrete and WM-100, the bulk density decreased $43 \%$ that showed in Fig. 3. The several researches [5], [17]-[20] reported that use of lighter materials replaced normal aggregate can reduce the density of concrete. It was cause from the most of lightweight aggregate are high porous materials that increases the volume of pore in LWAC [15]. According to Bakri et al. [6] reported that level of replacement of ceramic wastes in concrete reduced the density and increased $w / c$ ratio.

The increase of water absorption of all LWAC depended on levels of DWM that were showed in Fig. 3. The water absorption of LWAC increased from $2.49 \%$ to $16.33 \%$ when the DWM loading increased from 0 to $100 \mathrm{wt} . \%$. The water absorption of LWAC with 100 wt.\% of DWM was higher than and controls concrete about 6.5 times. It was cause of high waster adsorption of DWM (41.21\%). Lo et al. [20] reported that the water absorption of concrete increased when the level of lightweight aggregate increased. The increase of the lightweight aggregate loading increased the void and the percentage of pore area in the LWAC that was caused of reduction of strength and density but increase of waster adsorption. The high water adsorption of LWAC influenced to interfacial zone of lightweight aggregate concrete. This was cause of reduction of the cohesion between DWM and cement paste because the excess water covered the surface of aggregate that protected the cement paste. It made the gap between aggregate and cement paste.

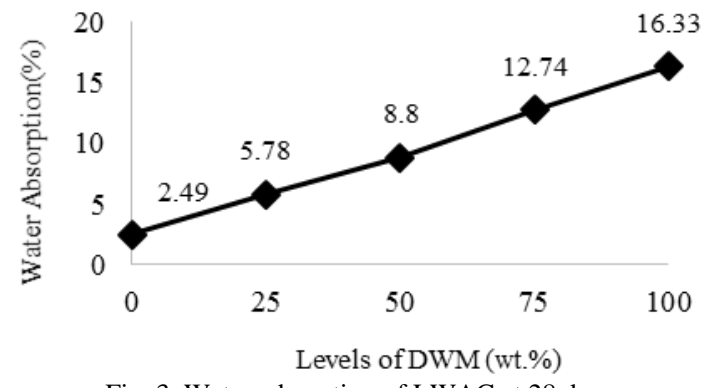

Fig. 3. Water adsorption of LWAC at 28 days.

\section{B. Effect Biscuit as Fine Aggregate on Engineering Properties of LWAC}

The optimum ratio of LWAC was observed in $50 \mathrm{wt} \%$ of DWC that have the compressive strength bulk density and water absorption meet the ASTM C330-14. So this research studied the effect of levels of biscuit substitution the fine aggregate on mechanical properties of LWAC. The level of biscuit replaced fine aggregate at 0, 25, 50, 75 and $100 \mathrm{wt} . \%$ were studied in this topic. The compressive strength of the LWAC with varies levels of biscuit are presented in Fig. 4. This compressive strength increased from 38.1 to $43.9 \mathrm{MPa}$ with increasing of biscuit from 0 to $50 \mathrm{wt} . \%$. Because of biscuit is one of ceramic type and have high strength. When it was filled in pore of LWAC and lead to increase of compressive strength. In addition, biscuit have amount of small size (less than $3 \mathrm{~mm}$ about $49 \mathrm{wt} . \%$ ) that was higher than sand. It can fill in pore of LWAC that increased the compressive strength. At levels of biscuit of 75 and $100 \mathrm{wt} . \%$ were added in concrete reduced the compressive strength from 43.9 to $23.4 \mathrm{MPa}$. It is possible that the high levels of biscuit increased the water to cement ratio that increased from 0.73 to 0.80 and lead to reduction of strength [18], [19].

Fig. 5 shows the relationship between levels of biscuit and the bulk density of LWAC containing 50wt.\% DWM. The reduction of bulk density of LWAC was found when the levels of biscuit replacement increase. At 25 and $50 \mathrm{wt} \%$ of biscuit, the bulk density of LWAC little decreased from 1803 to 1784 and $1776 \mathrm{~kg} / \mathrm{m} 3$ that reduced about 1.1 and $1.15 \%$ compared LWAC without biscuit. The little reduction of bulk density results from the specific gravity of biscuit (2.16) was lower than sand (2.4) about $10 \%$. This results related with the 
increase of compressive strength of LWAC with DWM containing 25 and $50 \mathrm{wt} . \%$ of biscuit. In addition, the water to cement ratio of both mixed $(0.73$ and 0.77$)$ were lower than LWAC containing 75 and 100 wt.\% of biscuit $(0.79$ and 0.80). The bulk density of LWAC with 50 wt.\% DWM containing 75 and 100 wt.\% of biscuit have 1698 and 1585 $\mathrm{kg} / \mathrm{m} 3$ that decreased about 5.9 and $12.1 \%$ compared with sample no biscuit. The percentage of reduction of bulk density increased because of the amount of biscuit and water to cement ratio in mixes increased. This lead to reduction of compressive strength. The water absorption of the LWAC with $50 \mathrm{wt} \%$ DWM containing difference levels of biscuit are showed in Fig. 6. Poon and Lam [21] reported that the amount of water absorption increased as the levels of aggregate replacement increased. The water absorption on LWAC increased from 8.08 to 8.84, 10.2, 11.59 and $13.22 \%$ when the levels of biscuit loading increased from 0 to 100 wt.\%. The increase of a little water absorption results from addition of biscuit to substitute find aggregate. It had water absorption at $24 \mathrm{hr}$. of biscuit about $5.79 \%$ that was higher than sand $(3.68 \%)$.

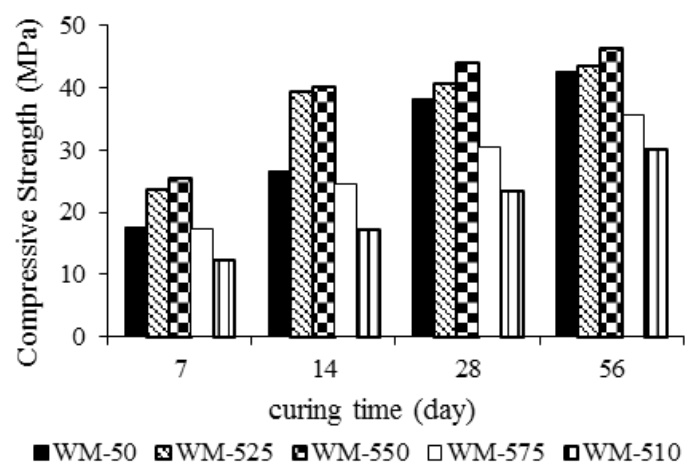

Fig. 4. Compressive strength of LWAC containing $50 \mathrm{wt} . \%$ of DWM with difference levels of biscuit replaced FA.

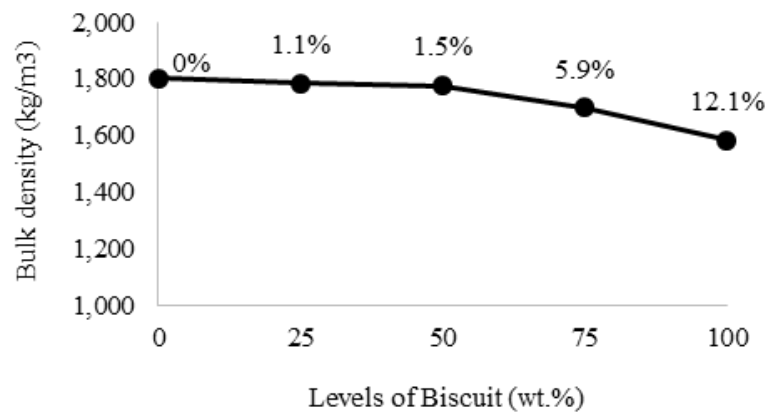

Fig. 5. Effect of levels of biscuit on bulk density of LWAC containing 50 wt.\% of DWM with difference levels of biscuit replaced FA.

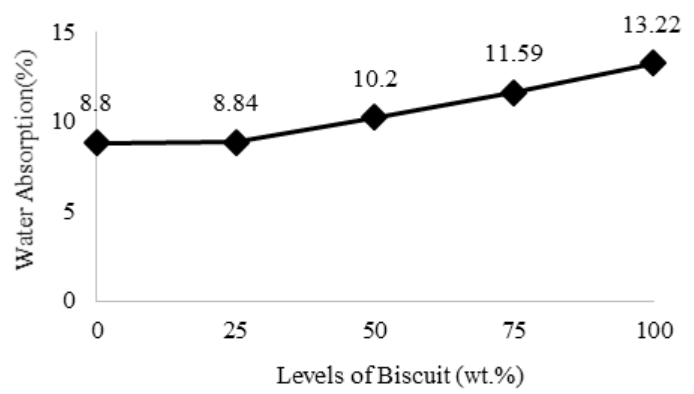

Fig. 6. ffect of biscuit loading on water adsorption of LWAC with $50 \mathrm{wt} . \%$ DWM.

\section{Thermal Conductivity}

The normal concrete, LWAC with 50 wt.\% of DWM containing 0 and $100 \mathrm{wt} . \%$ of biscuit were collected to study thermal conductivity properties that showed in Table 4 . The results of the thermal conductivity and density at 28-days of normal concrete was $1.201 \mathrm{~W} / \mathrm{m}^{\circ} \mathrm{K}$ and $2,395 \mathrm{~kg} / \mathrm{m}^{3}$. When 50 wt.\% of DWM was added into LWAC, the thermal conductivity decreased to $0.689 \mathrm{~W} / \mathrm{m}^{\circ} \mathrm{K}$. It was cause of the properties of DWM that have gypsum as major composition and porous material. DWM at $50 \mathrm{wt}$.\% into LWAC decreased the thermal conductivity about $42 \%$ compared with normal concrete. In addition, thermal conductivity and density decreased to $0.592 \mathrm{~W} / \mathrm{m}^{\circ} \mathrm{K}$ and $1,584 \mathrm{~kg} / \mathrm{m}^{3}$ when $100 \mathrm{wt} . \%$ of biscuit was added in LWAC containing $50 \mathrm{wt} \%$ DWM. The reduction of thermal conductivity of LWAC resulted from properties DWM and biscuit as lightweight aggregate.

TABLE IV: THE THERMAL CONDUCTIVITY OF LWAC

\begin{tabular}{lrc}
\hline \hline Sample & $\begin{array}{c}\text { Density } \\
\left(\mathrm{kg} / \mathrm{m}^{3}\right)\end{array}$ & \multicolumn{2}{c}{$\begin{array}{c}\text { Thermal Conductivity, } \mathrm{k} \\
\left(\mathrm{W} / \mathrm{m}^{\circ} \mathrm{K}\right)\end{array}$} \\
\hline Control & 2,395 & 1.201 \\
WM-50 & 1.803 & 0.689 \\
WM-510 & 1,584 & 0.592 \\
\hline \hline
\end{tabular}

\section{CONCLUSION}

The experimental results showed that the compressive strength, bulk density and thermal conductivity decreased but water absorption decreased when the level of DWM and biscuit loading increased. The optimum ratio of LWAC with ceramic wastes that meet the ASTM C330 was concrete replaced coarse aggregate with $50 \mathrm{wt} . \%$ of DWM and fine aggregate with 100 wt. $\%$ of biscuit. It was compressive strength, bulk density, water absorption and thermal conductivity of $23.4 \mathrm{MPa}, 1584 \mathrm{~kg} / \mathrm{m} 3,13.22 \%$ and 0.592 $\mathrm{W} / \mathrm{m}^{\circ}$ that meet to the ASTM C330 standard for structural lightweight aggregate concrete.

\section{ACKNOWLEDGMENT}

The authors wish to express their thankfulness to Patra Porcelain Co., Ltd., Saraburi for supplying working mold and biscuit as lightweight aggregate. Special thanks to the technical staff of King Mongkut's University of Technology Thonburi, Department of Civil Technology Education, Faculty of Industrial Education and Technology for their help during laboratory testing.

\section{REFERENCES}

[1] O. Onal, T. Uygunoglu, and A. Yildiz, "Investigation of properties of low strength lightweight concrete for thermal insulation," Build Environmental, vol. 42, no. 2, pp. 584-590, November 2005.

[2] A. A. Hilal, N. H. Thom, and A. R. Dawson, "The use of additives to enhance properties of pre-formed fomed concrete," International Journal of Engineering and Technology," vol. 7, no. 4, pp. 286-293, August 2015.

[3] P. Shafigh, H. B. Mahmud, M. Z. B. Jumaat, R. Ahmmad, and S. Bahri, "Structural lightweight aggregate concrete using two types of waste from the palm oil industry as aggregate," Journal of Cleaner Production, vol. 80, pp. 187-196, May 2014.

[4] S. M. F. Green, N. J. Brook, L. G. McSaveney, and J. M. Ingham, "Mixture design development and performance verification of structural lightweigtht pumice aggregate concrete," Journal of Materials Civil Engineering, vol. 23, pp. 1211-1219, August 2011. 
[5] B. Zhang and C. S. Poon, "Use of furnace bottom ash for producing lightweight aggregate concrete with thermal insulation properties," Journal of Cleaner Production, vol. 99, pp. 94-100, March 2015.

[6] A. M. M. A. Bakri, M. N. Norazian, H. Kamarudin, M. Salleh, and A Alida, "Strength of concrete based cement using recycle ceramic waste as aggregate," Advanced Material Research, vol. 740, pp. 734-738, Augest 2013.

[7] The concrete society. Lightweight concrete. [Online]. Available: http://www.concrete.org .uk

[8] American Concrete Institute (ACI), "Guide for structural lightweight aggregate concrete," ACI Manual of Concrete Practice, Part 1: Materials and General Properties of Concrete, ACI 213R-04, Farmington Hill, MI, 2003.

[9] L. Punsukumtana, "Plaster and recycling," Ceramics Journals Thailand, vol. 31, pp. 34-36, May-August 2009.

[10] American Society of Testing Materials, "Standard test method for slump of hydraulic cement concrete (ASTM C143M - 05)," 2005.

[11] American Society of Testing Materials, "Standard test method for compressive strength of concrete (ASTM C39-15)," 2015.

[12] American Concrete Institute, "Guide forr structural lightweight aggregate concrete (ACI Committee 213R)," 2003.

[13] American Society of Testing Materials, "Standard test method for densit, absorption and void of hardened concrete (ASTM C642-13)," 2013.

[14] American Society of Testing Materials, "Standard test method for thermal conductivity of refractories by hot wire (platinum resistance thermometer technique) (ASTM C1113 - 04))," 2004

[15] A. Martnok, "A study of effect of moisture states and absorption of natural aggregates on slump and compressive strength of concrete," Ph.D. dissertation, Dept. Civil Eng., Suranaree University of Technology, Nakhon Ratchasima, Thailand, 2013.

[16] American Society of Testing Materials, "Standard specification for lightweight aggregates for structural concrete (ASTM C330 - 14))," 2014.

[17] H. Oktay, R. Yumrutas, and A. Akpolat, "Mechanical and thermophysical properties of ligthweight aggregate concrete," Construction and Building Materials, vol. 96, pp. 217-225, 2015.

[18] K. M. A. Hossain, "Properties of volcanic pumice based cement and lightweight concrete," Cement and Concrete Research, vol. 34, pp. 283-291, September 2004.
[19] S. Kou and C. Poo, "Properties of concrete prepared with crushed fine stone, furnace buttom ash and fine recycled aggregates," Construction Building Matertals, vol. 8, pp. 2877-2886, March 2009.

[20] T. Y. Lo, H. Z. Cui, W. C. Tang, and W. M. Leung, "The effect of aggregate absorption on pore area at interfacial zone of lightweight concrete," Construction Building Masterials, vol. 22, pp. 623-628, December 2008.

[21] C. S. Poon and C. S. Lam, "The effect of aggregate-to-cement ratio and types of aggregates on the properties of precast concrete blocks," Cement and Concrete Composites, vol. 30, pp. 283-289, October 2000

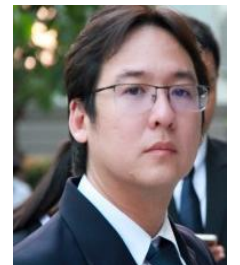

Rungroj Piyaphanuwat was born on December 29 , 1980 in Bangkok, Thailand. He received the bachelor degree in civil education technology in 2003 and the master/Ph.D. degrees in environmental technology in 2006 and 2010 from King Mongkut's Institute of Technology Thonburi, Thailand. During Ph.D. program, he went to Department of Chemistry from University of Aberdeeen in order to studied and made a part of my research for 6 months.

After graduation, worked as a faculty member for 2 years at the Department of Civil Education Technology and 1 year and 6 months at the King Mongkut's University of Technology Thonburi (Ratchaburi). Current his research interests are related to cement chemistry, concrete technology, waste utilization, construction material, environmental technology, and hazardous and solid waste management.

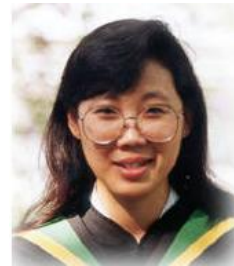

Suwimol Asavapisit works in environmeatal technology, School of Energy Environtment and Matreials, King Mongkut's University of Technology Thonburi. Her current research interests are related to cement chemistry, concrete technology, waste utilization, environmental technology, geopolymer, cement clinker and hazardous and solid waste management. 